\title{
The effects of epidermal growth factor and insulin-like growth factor I on the metabolic activity, nuclear maturation and subsequent development of cattle oocytes in vitro
}

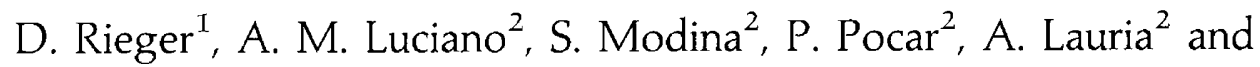 \\ F. Gandolfi ${ }^{2}$ \\ ${ }^{1}$ Animal Biotechnology Embryo Laboratory, Department of Biomedical Sciences, University of Guelph, \\ Guelph, Ontario, Canada, N1G 2W1; and 'Istituto di Anatomia degli Animali Domestici, \\ Università degli Studi di Milano, Via Trentacoste 2, 20134 Milan, Italy
}

\begin{abstract}
The effects of epidermal growth factor (EGF) and insulin-like growth factor I (IGF-I) on the maturation and subsequent development of cattle oocytes in vitro were evaluated in three experiments. Cumulus-oocyte complexes (COC) were collected from cattle ovaries and matured for $20-24 \mathrm{~h}$ in control medium or in medium containing $50 \mathrm{ng} \mathrm{EGF} \mathrm{ml}^{-1}, 100 \mathrm{ng}$ IGF-I ml ${ }^{-1}, E G F+$ IGF-I, or $10 \%(v / v)$ fetal calf serum plus 0.1 i.u. human menopausal gonadotrophin $\mathrm{ml}^{-1}$ (hMG). In Expt 1, treatment with EGF + IGF-I stimulated cumulus expansion, the metabolism of pyruvate and glutamine, and nuclear maturation. In Expt 2, only the metabolic measurements from oocytes that reached metaphase II were considered, and EGF + IGF-I stimulated pyruvate metabolism to the same extent as serum + hMG. In Expt 3, the oocytes were fertilized after maturation culture, and the resultant embryos cultured for up to 8 days. The cleavage was greater in the EGF and EGF + IGF-I groups than in the controls but less than in the serum $+\mathrm{hMG}$ group. Moreover, the number of blastocyst cells at 7 days after insemination and the proportion of cleaved embryos that developed to the blastocyst stage by day 8 was greater in the serum +hMG group than in the control group indicating that maturation treatment can affect early embryonic development. In conclusion, EGF + IGF-I can stimulate cumulus expansion, oxidative metabolism, nuclear maturation and cleavage after fertilization of bovine oocytes in vitro. The relative effects of the treatments on oocyte pyruvate metabolism in Expts 1 and 2 generally paralleled their effects on cleavage and subsequent development in Expt 3, suggesting that mitochondrial function is related to developmental potential. Further investigation is required to determine which component(s) of serum or gonadotrophin treatment is responsible for the effects on subsequent embryonic development.
\end{abstract}

\section{Introduction}

In mammals, oocytes are arrested at the diplotene stage of prophase of the first meiotic division (Tsafriri, 1985). In vivo, nuclear maturation to metaphase II is stimulated by the preovulatory LH surge, but the intrafollicular mechanism is not well understood (Mattioli, 1992). In vitro, bovine oocytes undergo spontaneous nuclear maturation when they are removed from the follicle, but formation of the male pronucleus after fertilization and subsequent embryonic development are limited (Crozet, 1991). The addition of high concentrations of gonadotrophins, or serum containing circulating concentrations of gonadotrophins, to the maturation medium results in improved rates of embryo development (Crozet, 1991). The positive effects of gonadotrophins on oocyte maturation are mediated through the cumulus cells, but it is not clear whether

Received 5 June 1997. these effects result from interaction with gonadotrophin receptors on the cumulus cells, or from crossreaction with the receptors for cellular growth factors (Brackett and Zuelke, 1993; Harper and Brackett, 1993).

A variety of cellular growth factors including members of the transforming growth factor $\alpha$ family, transforming growth factor $\beta$, fibroblast growth factors, tumour necrosis factor, interleukin 1 , insulin-like growth factor $I$ (IGF-I), insulin-like growth factor 2, and epidermal growth factor (EGF) are found in the ovary and have effects on ovarian cell function (Dorrington et al., 1987; Hammond et al., 1991; Adashi, 1992; Stern and Coulam, 1992; Hammond et al, 1993). In particular, IGF-I has been shown to stimulate or enhance the in vitro maturation of pig (Reed et al., 1993; Xia et al., 1994) and cattle (Harper and Brackett, 1993) oocytes. Epidermal growth factor has been shown to stimulate the in vitro maturation of mouse (Downs, 1989), rat (Benyosef et al., 1992), human (Das et al., 1991), pig (Reed et al., 1993; Ding and Foxcroft, 1994) and 
cattle (Park and Lin, 1993; Kobayashi et al., 1994; Lonergan et al., 1996) oocytes. When added to maturation medium containing a relatively low concentration of $\mathrm{FSH}, \mathrm{EGF}$ increased the proportion of cattle oocytes that developed to the blastocyst stage after fertilization (Harper and Brackett, 1993). Lorenzo et al. (1994) have shown that IGF-I and EGF together stimulate nuclear maturation in a greater proportion of cattle oocytes than does either growth factor alone.

In addition to changes in protein synthesis (Kastrop et al., 1991), and in the distribution of cortical granules and mitochondria (Hyttel et al., 1986; Shamsuddin et al., 1993), the nuclear maturation of cattle oocytes in the presence of gonadotrophins is accompanied by increases in the metabolism of glutamine, pyruvate and glycine (Zuelke and Brackett, 1993; Rieger and Loskutoff, 1994), but not glucose (Zuelke and Brackett, 1992; Rieger and Loskutoff, 1994). The results of these studies suggest that oxidative metabolism increases, and is the major form of cellular energy production, during maturation of the cattle oocyte in vitro.

The first objective of the present study was to determine whether the stimulation of maturation of cattle oocytes by IGF-I and EGF is similarly accompanied by changes in metabolic activity. The second objective was to determine the effects of treatment of bovine oocytes with EGF and IGF-I during maturation on the subsequent cleavage and development of embryos formed from those oocytes. Some of the data presented here have been published as abstracts (Rieger et al., 1995; Gandolfi et al., 1996).

\section{Materials and Methods}

The study comprised three experiments. In Expt 1 , the cumulus expansion, metabolic activity, and nuclear maturation of cattle oocytes were determined immediately after recovery from the ovary or after in vitro maturation for $20 \mathrm{~h}$ in the absence or presence of EGF, IGF-I, human menopausal gonadotrophin (hMG) and serum. In Expt 2, oocytes were subjected to the same maturation treatments and the effect of treatment on metabolic activity of those oocytes that reached metaphase II was evaluated. In Expt 3, the oocytes were subjected to the same maturation treatments and then fertilized in vitro. The effects of the treatment on cleavage, development to the blastocyst stage and number of cells at the blastocyst stage were determined. Unless otherwise indicated, all reagents were purchased from Sigma Chemical Co. (St Louis, MO).

\section{Oocyte collection}

Ovaries were collected from local abattoirs in sterile phosphate-buffered saline (PBS) and transported to the laboratory in a warm box at $28^{\circ} \mathrm{C}$ within $2 \mathrm{~h}$ after death of the animals. Most of the animals were of the Holstein-Friesen breed, and approximately three to ten years old.

Cumulus-oocyte complexes (COC) were isolated by slicing the surface of the ovaries with a sterile scalpel blade ( $X_{u}$ et al. 1992) and rinsing them in $50 \mathrm{ml}$ TCM 199 supplemented with

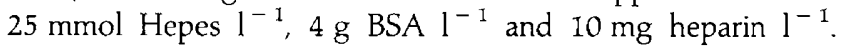
Selected COC with several complete layers of granulosa cells surrounding an oocyte with a homogeneous cytoplasm were rinsed three times in $2 \mathrm{ml}$ of the same medium and then randomly distributed among the treatment groups.

\section{Maturation treatments and evaluation of cumulus expansion}

The basic medium for oocyte maturation was TCM 199 containing $0.68 \mathrm{mmol}$ L-glutamine $\mathrm{I}^{-1}$ and supplemented with $25 \mathrm{mmol} \mathrm{NaHCO}_{3} \mathrm{I}^{-1}$ and $0.1 \%(\mathrm{w} / \mathrm{v})$ polyvinylalcohol. To

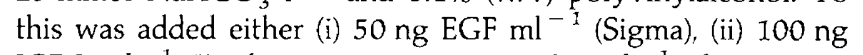
IGF-I ml ${ }^{-1}$ (Boehringer), (iii) $50 \mathrm{ng}$ EGF ml $\mathrm{ml}^{-1}$ plus $100 \mathrm{ng}$ IGF-I $\mathrm{ml}^{-1}$, or (iv) $10 \%(\mathrm{v} / \mathrm{v})$ fetal calf serum plus 0.1 i.u. human menopausal gonadotrophin $\mathrm{ml}^{-1}$ (hMG, Pergovet, Serono, Rome). The control treatment was the basic medium only.

For each treatment, droplets were prepared containing 5 to 11 COC at a concentration of 1 COC per $10 \mu \mathrm{l}$ and cultured for $20 \mathrm{~h}$ at $38.5^{\circ} \mathrm{C}$ under paraffin oil (Sigma) in a humidified atmosphere of $5 \% \mathrm{CO}_{2}$ in air. In Expt 1 , cumulus expansion was then evaluated under a stereomicroscope at $\times 16$.

\section{Metabolic measurements}

The metabolism of individual oocytes (Expts 1 and 2) was measured using TCM 199 containing $0.68 \mathrm{mmol}$ L-glutamine $\mathrm{I}^{-1}$ and supplemented with $25 \mathrm{mmol} \mathrm{NaHCO}_{3} \mathrm{~L}^{-1}, 20 \mathrm{mmol}$ Hepes $\mathrm{I}^{-1}$, and $0.1 \%(\mathrm{w} / \mathrm{v})$ polyvinylalcohol.

After culture in the maturation treatments for $20 \mathrm{~h}$, approximately $10 \mathrm{COC}$ were taken at random from each maturation treatment group, placed in $10 \mathrm{mmol}$ sodium citrate $1^{-1}$ for 5 min and pipetted up and down repeatedly to remove the cumulus cells. The denuded oocytes were then washed three times in PBS before being transferred to metabolic measurement medium. In Expt $1, C O C$ were also recovered from fresh ovaries and denuded in the same way as the oocytes in the cultured groups. For each replicate, usually eight denuded oocytes of each group were then subjected to the metabolic measurement procedure. The remaining denuded oocytes were contemporaneously cultured in $0.5 \mathrm{ml}$ of metabolic measurement medium (without radiolabelled substrates) at $38.5^{\circ} \mathrm{C}$ under $5 \% \mathrm{CO}_{2}$ in humidified air.

Except for the medium, the technique used to measure oocyte metabolism was as described by Rieger and Loskutoff (1994). Mixtures of D- $\left[5-{ }^{3} \mathrm{H}\right]$ glucose (specific activity $=16.6 \mathrm{Ci}$ $\mathrm{mmol}^{-1}$, Amersham International, Little Chalfont) and L- $\left[{ }^{14} \mathrm{C}(\mathrm{U})\right] g$ glutamine $\left(271 \mathrm{mCi} \mathrm{mmol}{ }^{-1}\right.$, Amersham), or D-[5$\left.{ }^{3} \mathrm{H}\right]$ glucose and $\left[2 \cdot{ }^{14} \mathrm{C}\right.$ pyruvate $\left(31.1 \mathrm{mCi} \mathrm{mmol}^{-1}\right.$, NEN Products Division, Dupont, Nemours), or $\left[2-{ }^{14} \mathrm{C}\right]$ pyruvate alone were dried by vacuum evaporation. The radiolabels were then taken up in metabolic measurement medium to give concentrations of $0.12 \mu \mathrm{Ci} \mu l^{-1}, 0.18 \mu \mathrm{Ci} \mu l^{-1}$, and $0.14 \mu \mathrm{Ci} \mu]^{-1}$, for $\mathrm{D}-\left[5{ }^{3} \mathrm{H}\right]$ glucose, $\left.\mathrm{L}-{ }^{14} \mathrm{C}(\mathrm{U})\right]$ glutamine and $\left[2-{ }^{14}\right.$ C]pyruvate, respectively.

Individual oocytes were taken up in $2 \mu \mathrm{l}$ of metabolic measurement medium and placed in the cap of a sterile $2.5 \mathrm{ml}$ polypropylene screw-cap microtube together with $2 \mu \mathrm{l}$ of radiolabelled substrate mixture (total culture volume $4 \mu \mathrm{l}$ ) to yield final concentrations (labelled plus unlabelled) of

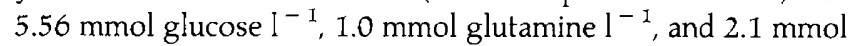
pyruvate $I^{-1}$. The cap was quickly fitted onto the tube, which 
had been loaded with $1.5 \mathrm{ml}$ of $25 \mathrm{mmol} \mathrm{NaHCO}_{3} \mathrm{I}^{-1}$ equilibrated with a gas mixture of $5 \% \mathrm{O}_{2}, 5 \% \mathrm{CO}_{2}$ and $90 \%$ $\mathrm{N}_{2}$. Five or six sham preparations, containing all reagents but no oocyte, were included for each preparation of labelled substrates. These served to control for all non-specific counts due to machine background, chemiluminescence, bacterial contamination, and spontaneous breakdown of the labelled substrate. At the end of the $3 \mathrm{~h}$ measurement period, the caps were removed and the bicarbonate was mixed with $15 \mathrm{ml}$ of scintillation fluid and counted for $5 \mathrm{~min}$ in a liquid scintillation counter. The total d.p.m. of labelled substrate was determined by mixing $2 \mu \mathrm{l}$ of the labelled substrate solution with $1.5 \mathrm{ml}$ of $25 \mathrm{mmol} \mathrm{NaHCO}_{3} \mathrm{I}^{-1}$, and counting in the same way. The amount of each substrate metabolized by each oocyte was calculated as described for cattle embryos (Rieger et al., 1992).

\section{Evaluation of nuclear maturation}

Immediately after the metabolic measurements, the denuded oocytes were washed three times and then fixed by immersion for $24 \mathrm{~h}$ in a solution of acetic acid and ethanol (1:3). After staining with $1 \%(? / \mathrm{v})$ Lacmoid, the nuclear morphology was examined at $\times 250$, and classified as immature (germinal vesicle or germinal vesicle breakdown stage), intermediate (metaphase I, anaphase I or telophase I), or mature (metaphase II) as described by Sirard and Bilodeau (1990). Oocytes that could not be identified as being at any of these stages were classified as degenerate. In Expt 1, the oocytes from each replicate of each treatment were fixed, stained and evaluated as a group. In Expt 2, the oocytes were fixed, stained and evaluated individually.

\section{In vitro fertilization and embryo culture}

In Expt 3, COC were matured for $20 \mathrm{~h}$ using the treatments described above. A straw containing cryopreserved bull spermatozoa was thawed in water at $25^{\circ} \mathrm{C}$ and the cells were layered on top of a 45-90\% Percol gradient made with modified Tyrode's medium (TALP); the gradient was centrifuged for $30 \mathrm{~min}$ at $600 \mathrm{~g}$. The sperm pellet was counted and diluted to a final concentration of $1 \times 10^{6}$ spermatozoa $\mathrm{ml}^{-1}$ medium TALP, supplemented with $0.3 \%$ BSA fatty acid free, $10 \mu \mathrm{g}$ heparin $\mathrm{ml}^{-1}$ and $5 \mathrm{mmol}$ caffeine $\mathrm{l}^{-1}$. Microdrops of $90 \mu \mathrm{l}$ were made with the sperm suspension and mineral oil was layered on top.

Groups of 30 oocytes were denuded by vortexing for $4 \mathrm{~min}$ in $500 \mu \mathrm{l}$ of Hepes-buffered TALP medium and washed twice before being transferred into the fertilization drops. Between 8 and 12 oocytes, in a volume of $10 \mu \mathrm{l}$, were added to each drop and were incubated at $38.5^{\circ} \mathrm{C}$ in an humidified atmosphere of $5 \% \mathrm{CO}_{2}$ in air for $18-20 \mathrm{~h}$.

Bovine oviducts were obtained from the abattoir at the same time as the ovaries, and the epithelial cells were isolated by scraping the lumen of the ampullary region with a Pasteur pipette and then were washed twice in $5 \mathrm{ml}$ Hepes-buffered (25 mmol $1^{-1}$ ) medium 199, supplemented with $0.4 \%$ BSA. Clusters of cells were cultured for $24-48 \mathrm{~h}$ in medium 199 supplemented with $100 \mathrm{mg}$ glutamine $\mathrm{l}^{-1}, 75 \mathrm{mg}$ kanamicine $\mathrm{I}^{-1}, 2.1 \mathrm{~g}$ sodium bicarbonate $\mathrm{I}^{-1}$ and $10 \%(\mathrm{v} / \mathrm{v})$ fetal calf serum, before being divided into $20 \mu \mathrm{l}$ aliquots containing approximately 5000 cells. At the end of the fertilization period putative zygotes were rinsed twice in medium 199 and then transferred in groups of ten in the culture drops. Incubation was performed as described above and the cleaved eggs were transferred to a second drop containing previously prepared oviduct cells, after 2 days of culture. On day 7 after insemination, the embryos judged to have reached the blastocyst stage were removed from culture. The metabolism of glutamine and glucose by individual embryos was measured over $3 \mathrm{~h}$, by culture in a $4 \mu \mathrm{l}$ hanging microdrop containing the radiolabelled substrates, over $1.5 \mathrm{ml}$ of $25 \mathrm{mmol} \mathrm{NaHCO}_{3} \mathrm{l}^{-1}$, as described above for the oocytes. They were then stained as described above for an accurate determination of number of nuclei. The remaining embryos were left in culture for a further $24 \mathrm{~h}$ (day 8) and those that were judged to have reached the blastocyst stage were fixed and stained in the same way.

\section{Statistical analysis}

In Expt 1, the effect of treatment on cumulus expansion was evaluated by first calculating the arcsines of the proportion of expanded COC in each replicate ( $n=25$ or 26 per treatment). These values were subjected to one-way analysis of variance, followed by Duncan's multiple-range tests to compare individual treatment means. The effect of treatment on the metabolism of each substrate was analysed by one-way analysis of variance, followed by Duncan's multiple-range tests to compare individual treatment means. The effect of the metabolic measurement procedure on nuclear maturation was evaluated by Chi-square analyses of the proportion of mature oocytes following metabolic measurement or contemporaneous culture. The arcsines of the proportion of oocytes in each class of nuclear maturation in each replicate ( $n=7$ per treatment) were calculated and these values were subjected to one-way analysis of variance, followed by Duncan's multiple-range tests to compare individual treatment means.

In Expt 2, only the metabolic measurements from oocytes that had reached metaphase II were included in the statistical analysis. These data were subjected to one-way analysis of variance, followed by Duncan's multiple-range tests to compare individual treatment means.

In Expt 3, the arcsines of the proportions of oocytes that cleaved or reached the blastocyst stage by day 7 or 8 in each replicate ( $n=12$ per treatment) were subjected to one-way analysis of variance, followed by Duncan's multiple-range tests to compare individual treatment means. The effects of treatment on the metabolism of glutamine and glucose by individual blastocysts, and on the number of cells in the blastocysts, were analysed by one-way analysis of variance, followed by Duncan's multiple-range tests to compare individual treatment means.

\section{Results}

\section{Experiment 1}

A total of 1148 COC was used to evaluate the effects of maturation treatment on cumulus expansion. Overall, there was 
Table 1. The effect of maturation treatment on the metabolism of glucose, glutamine and pyruvate by individual denuded cattle oocytes (Expt 1)

\begin{tabular}{|c|c|c|c|c|c|c|}
\hline \multirow[b]{2}{*}{ Treatment } & \multicolumn{2}{|c|}{ Glucose } & \multicolumn{2}{|c|}{ Glutamine } & \multicolumn{2}{|c|}{ Pyruvate } \\
\hline & $\begin{array}{c}\text { Number of } \\
\text { oocytes }\end{array}$ & $\begin{array}{c}\text { (pmol per } \\
\text { oocyte per } 3 \mathrm{~h} \text { ) }\end{array}$ & $\begin{array}{c}\text { Number of } \\
\text { oocytes }\end{array}$ & $\begin{array}{c}\text { (pmol per } \\
\text { oocyte per } 3 \text { h) }\end{array}$ & $\begin{array}{c}\text { Number of } \\
\text { oocytes }\end{array}$ & $\begin{array}{c}\text { (pmol per } \\
\text { oocyte per } 3 \mathrm{~h} \text { ) }\end{array}$ \\
\hline Non-cultured & 24 & $4.8 \pm 1.2$ & 16 & $0.9 \pm 0.3^{\mathrm{a}}$ & 12 & $4.6 \pm 2.1^{a}$ \\
\hline Control & 48 & $5.6 \pm 1.0$ & 32 & $2.4 \pm 0.3^{\mathrm{b}}$ & 24 & $7.4 \pm 1.4^{a}$ \\
\hline EGF & 44 & $3.7 \pm 1.1$ & 28 & $2.9 \pm 0.2^{b c}$ & 24 & $13.2 \pm 1.5^{b}$ \\
\hline IGF-I & 44 & $5.3 \pm 0.9$ & 29 & $2.9 \pm 0.2^{b c}$ & 19 & $19.7 \pm 1.6^{\mathrm{c}}$ \\
\hline $\mathrm{EGF}+\mathrm{IGF}-\mathrm{I}$ & 46 & $3.8 \pm 0.7$ & 30 & $3.2 \pm 0.2^{c}$ & 20 & $17.5 \pm 1.3^{b c}$ \\
\hline Serum + hMG & 45 & $4.6 \pm 0.9$ & 30 & $3.3 \pm 0.2^{c}$ & 23 & $20.4 \pm 1.7^{c}$ \\
\hline
\end{tabular}

The oocytes were denuded and metabolism measured for $3 \mathrm{~h}$, either immediately after recovery from the ovaries (non-cultured), or after culture for $20 \mathrm{~h}$ (all other groups). EGF: epidermal growth factor; IGF-I: insulin-like growth factor l; hMG: human menopausal gonadotrophin.

Values are means \pm SEM. ${ }^{\text {abc } W i t h i n ~ c o l u m n s, ~ v a l u e s ~ w i t h ~ d i f f e r e n t ~ s u p e r s c r i p t s ~ a r e ~ s i g n i f i c a n t l y ~ d i f f e r e n t ~}(P<0.05)$.

Table 2. The effect of maturation treatment on the nuclear maturation of cattle oocytes (Expt 1)

\begin{tabular}{lccccc}
\hline Treatment & $\begin{array}{c}\text { Total number } \\
\text { of oocytes }\end{array}$ & $\begin{array}{c}\text { Immature } \\
(\%)\end{array}$ & $\begin{array}{c}\text { Intermediate } \\
(\%)\end{array}$ & $\begin{array}{c}\text { Mature } \\
(\%)\end{array}$ & $\begin{array}{c}\text { Degenerate } \\
(\%)\end{array}$ \\
\hline Control & 66 & $4.4 \pm 2.1$ & $24.6 \pm 5.7$ & $27.7 \pm 4.8^{\mathrm{a}}$ & $43.2 \pm 6.1^{\mathrm{a}}$ \\
EGF & 63 & $1.4 \pm 1.4$ & $20.1 \pm 8.1$ & $54.0 \pm 9.5^{\mathrm{ab}}$ & $24.5 \pm 4.9^{\mathrm{b}}$ \\
IGF-I & 57 & $3.2 \pm 2.1$ & $17.0 \pm 7.2$ & $51.1 \pm 7.8^{\mathrm{ab}}$ & $28.6 \pm 8.7^{\mathrm{ab}}$ \\
EGF + IGF-I & 66 & $2.9 \pm 1.8$ & $12.0 \pm 6.7$ & $61.3 \pm 5.8^{\mathrm{b}}$ & $23.8 \pm 5.0^{\mathrm{b}}$ \\
Serum + hMG & 63 & $0.0 \pm 0.0$ & $34.3 \pm 10.4$ & $51.8 \pm 12.5^{\mathrm{ab}}$ & $13.8 \pm 2.9^{\mathrm{b}}$ \\
\hline
\end{tabular}

The oocytes were cultured for $20 \mathrm{~h}$, and then denuded of cumulus cells and subjected to metabolic measurement or culture for $3 \mathrm{~h}$ before being fixed and stained. EGF: epidermal growth factor; IGF-I: insulin-like growth factor I; hMG: human menopausal gonadotrophin. Proportions are means \pm SEM for seven replicates.

"Within columns, values with different superscripts are significantly different $(P<0.05)$.

a highly significant effect of treatment on the proportion of COC that expanded $(P<0.0001)$. There was no cumulus expansion in the control group $(0.0 \pm 0.0 \%$, mean \pm SEM, $n=234$ ). The proportion of expanded COC in the IGF-I group $(13.9 \pm 3.5 \%, n=224)$ was not different from that in the control group. Conversely, the proportion of expanded COC in the EGF $(31.1 \pm 5.1 \%, n=227)$, EGF + IGF-I $(56.8 \pm 6.3 \%$, $n=229)$ and serum + hMG $(100.0 \pm 0.0 \%, n=234)$ groups were all significantly different $(P<0.05)$ from that in the control group, and from each other.

Metabolic measurement were made on a total of 300 oocytes. The data from 13 oocytes $(4 \%)$ were judged to be erroneous and were therefore excluded from the analysis. The remaining 287 oocytes yielded 538 metabolic values (Table 1). There was a very highly significant overall effect $(P<0.0001)$ of treatment on both glutamine and pyruvate metabolism, but no significant effect $(P>0.60)$ on glucose metabolism.

Glutamine metabolism was significantly less $(P<0.05)$ in the non-cultured oocytes than in all other groups, but not different among the control, EGF and IGF-I groups or among the EGF, IGF-I, EGF + IGF-I and serum + hMG groups. However, glutamine metabolism in the EGF + IGF-I and serum + hMG groups was significantly greater than that in the control group.
Pyruvate metabolism was significantly greater in the EGF, IGF-I, EGF + IGF-I and serum + hMG groups than in the non-cultured and control groups, which were not different. The metabolism of pyruvate by the EGF + IGF-I group was not different from either the EGF or IGF-I group, but was significantly greater in the serum + hMG group than in the EGF group.

Of the 34 non-cultured oocytes, $47.1 \%$ were immature, $35.3 \%$ were intermediate, $0.0 \%$ were mature, and $17.7 \%$ were degenerate. For the cultured treatment groups, the overall proportions of mature oocytes were not different between those subjected to the metabolic measurement procedure (120/246, 48.8\%) and those that were contemporaneously cultured (37/69, 53.6\%).

There was no overall effect of treatment on the proportions of immature $(P>0.40)$ or intermediate $(P>0.30)$ oocytes, and no differences between individual treatment means (Table 2).

There was also no significant overall effect of treatment on the proportions of mature oocytes $(P>0.17)$. However, the proportion of mature oocytes in the EGF + IGF-I group was significantly greater than that in the control group. The proportions of mature oocytes in the EGF, IGF-I and serum $+\mathrm{hMG}$ groups were not different from the control group, the EGF + IGF-I group, or each other. 
Table 3. The effect of maturation treatment on the metabolism of glucose, glutamine and pyruvate by individual denuded cattle oocytes that had matured to metaphase II (Expt 2)

\begin{tabular}{|c|c|c|c|c|c|c|}
\hline \multirow[b]{2}{*}{ Treatment } & \multicolumn{2}{|c|}{ Glucose } & \multicolumn{2}{|c|}{ Glutamine } & \multicolumn{2}{|c|}{ Pyruvate } \\
\hline & $\begin{array}{c}\text { Number of } \\
\text { oocytes }\end{array}$ & $\begin{array}{c}\text { (pmol per } \\
\text { oocyte per } 3 \mathrm{~h} \text { ) }\end{array}$ & $\begin{array}{c}\text { Number of } \\
\text { oocytes }\end{array}$ & $\begin{array}{c}\text { (pmol per } \\
\text { oocyte per } 3 \mathrm{~h} \text { ) }\end{array}$ & $\begin{array}{c}\text { Number of } \\
\text { oocytes }\end{array}$ & $\begin{array}{c}\text { (pmol per } \\
\text { oocyte per } 3 \mathrm{~h} \text { ) }\end{array}$ \\
\hline Control & 26 & $4.7 \pm 0.5$ & 19 & $2.8 \pm 0.3$ & 18 & $9.6 \pm 1.3^{\mathrm{a}}$ \\
\hline EGF & 25 & $4.8 \pm 0.5$ & 19 & $2.6 \pm 0.3$ & 23 & $11.6 \pm 0.9^{\mathrm{ab}}$ \\
\hline IGF-I & 16 & $3.9 \pm 0.6$ & 20 & $2.7 \pm 0.3$ & 20 & $14.2 \pm 1.1^{b c}$ \\
\hline $\mathrm{EGF}+\mathrm{IGF}-\mathrm{I}$ & 24 & $5.2 \pm 0.6$ & 18 & $3.1 \pm 0.5$ & 26 & $16.7 \pm 0.9^{\mathrm{cd}}$ \\
\hline Serum + hMG & 35 & $4.2 \pm 0.5$ & 23 & $3.4 \pm 0.3$ & 25 & $18.1 \pm 1.3^{\mathrm{d}}$ \\
\hline
\end{tabular}

After culture for $20 \mathrm{~h}$ in the indicated maturation treatments, the oocytes were denuded and metabolism measured for $3 \mathrm{~h}$. The oocytes were then fixed and stained to evaluate the stage of nuclear maturation. EGF: epidermal growth factor; IGF-I: insulin-like growth factor I; hMG: human menopausal gonadotrophin. Metabolism values are means \pm SEM.

abcd Within columns, values with different superscripts are significantly different $(P<0.05)$.

Table 4. The effect of maturation treatment of cattle oocytes on the cleavage rate, development to the blastocyst stage, and number of cells in blastocyst (Expt 3)

\begin{tabular}{|c|c|c|c|c|c|c|c|c|c|c|}
\hline \multirow[b]{3}{*}{ Treatment } & \multirow{3}{*}{$\begin{array}{c}\text { Number } \\
\text { of } \\
\text { oocytes }\end{array}$} & \multirow[b]{3}{*}{$\begin{array}{c}\text { Cleaved } \\
(\%)\end{array}$} & \multicolumn{8}{|c|}{ Embryos that developed to the blastocyst stage } \\
\hline & & & \multicolumn{4}{|c|}{ By day 7} & \multicolumn{4}{|c|}{ By day 8} \\
\hline & & & $n$ & $\begin{array}{l}\text { Percentage } \\
\text { of oocytes }\end{array}$ & $\begin{array}{l}\text { Percentage } \\
\text { of cleaved }\end{array}$ & $\begin{array}{l}\text { Number of } \\
\text { cells }\end{array}$ & $n^{*}$ & $\begin{array}{l}\text { Percentage } \\
\text { of oocytes }\end{array}$ & $\begin{array}{l}\text { Percentage } \\
\text { of cleaved }\end{array}$ & $\begin{array}{c}\text { Number of } \\
\text { cells }^{+}\end{array}$ \\
\hline Control & 268 & $43.4 \pm 3.5^{\mathrm{a}}$ & 21 & $8.3 \pm 1.8^{\mathrm{a}}$ & $18.8 \pm 4.2$ & $77.9 \pm 6.8^{\mathrm{a}}$ & 32 & $12.3 \pm 2.5^{\mathrm{a}}$ & $27.3 \pm 5.3^{\mathrm{a}}$ & $81.7 \pm 11.5$ \\
\hline EGF & 271 & $53.9 \pm 3.7^{\mathrm{b}}$ & 31 & $11.3 \pm 2.6^{\mathrm{ab}}$ & $19.3 \pm 4.1$ & $70.8 \pm 4.3^{\mathrm{a}}$ & 50 & $18.4 \pm 2.4^{\mathrm{ab}}$ & $32.8 \pm 2.9^{\mathrm{ab}}$ & $74.0 \pm 7.0$ \\
\hline IGF-I & 268 & $51.3 \pm 3.7^{\mathrm{ab}}$ & 19 & $7.3 \pm 0.9^{\mathrm{a}}$ & $15.9 \pm 2.6$ & $72.8 \pm 5.6^{\mathrm{a}}$ & 32 & $12.8 \pm 1.9^{\mathrm{ab}}$ & $28.5 \pm 6.0^{\mathrm{ab}}$ & $67.6 \pm 6.9$ \\
\hline $\mathrm{EGF}+\mathrm{IGF}-\mathrm{I}$ & 276 & $57.9 \pm 3.6^{\mathrm{b}}$ & 32 & $12.3 \pm 2.2^{\mathrm{ab}}$ & $21.0 \pm 3.2$ & $80.1 \pm 5.1^{\mathrm{a}}$ & 56 & $21.0 \pm 2.0^{b}$ & $37.7 \pm 3.9^{\mathrm{ab}}$ & $74.6 \pm 5.9$ \\
\hline Serum + hMG & 267 & $73.5 \pm 3.5^{c}$ & 45 & $16.4 \pm 2.1^{b}$ & $22.7 \pm 2.6$ & $95.1 \pm 4.3^{\mathrm{b}}$ & 82 & $30.3 \pm 3.4^{\mathrm{c}}$ & $40.9 \pm 4.1^{b}$ & $82.1 \pm 5.5$ \\
\hline
\end{tabular}

The oocytes were matured for $20 \mathrm{~h}$ in the indicated treatments, fertilized in vitro, and then co-cultured with bovine oviductal epithelial cells until 7 or 8 days after insemination. EGF: epidermal growth factor; IGF-I: insulin-like growth factor I; hMG: human menopausal gonadotrophin. Proportions are mean \pm SEM for 12 replicates.

"Numbers and mean proportions include the blastocysts identified and removed from culture at day 7.

${ }^{\dagger}$ Mean cell numbers are for only the embryos identified as blastocysts at day 8 .

${ }^{a b c}$ Within columns, values with different superscripts are significantly different $(P \leq 0.05)$.

There was a significant overall effect of treatment on the proportions of degenerate oocytes $(P<0.05)$. The proportion of degenerate oocytes in the control group was significantly greater than that in the EGF, EGF + IGF-I, and serum + hMG groups. There were no differences in the proportion of degenerate oocytes among the EGF, IGF-I, EGF + IGF-I, and serum + hMG groups, or between the control and IGF-I groups.

\section{Experiment 2}

The effects of maturation treatment on the metabolism of glucose, glutamine and pyruvate by oocytes that matured to metaphase II are shown in Table 3. There was no significant overall effect of treatment group and no significant differences among treatments on glucose or glutamine metabolism. There was a highly significant overall effect of treatment on pyruvate metabolism $(P<0.0001)$. There was no significant difference in pyruvate metabolism between the EGF and control groups, between EGF and IGF-I, IGF-I and EGF + IGF-I, or EGF + IGF-I and serum + hMG. However, pyruvate metabolism by the IGF-I and EGF + IGF-I groups was significantly greater $(P<0.05)$ than for the controls, and was greater in the serum $+\mathrm{hMG}$ group than in all other groups except $\mathrm{EGF}+\mathrm{IGF}-\mathrm{I}$.

\section{Experiment 3}

There was a highly significant overall effect of maturation treatment on cleavage rate $(P<0.0001)$ : it was lowest in the controls, intermediate in the EGF, IGF-I and EGF + IGF-I groups, and highest in the serum $+\mathrm{hMG}$ group (Table 4 ).

There was a significant overall effect of treatment on the proportion of oocytes that developed to the blastocyst stage by day $7(P<0.02)$, but only the serum + hMG group was significantly different from the controls. However, there was no 
Table 5. The effect of maturation treatment of cattle oocytes on the metabolism of glutamine and glucose at the blastocyst stage (Expt 3)

\begin{tabular}{lccc}
\hline Treatment & $n$ & $\begin{array}{c}\text { Glutamine } \\
\text { (pmol per } \\
\text { embryo per 3 h) }\end{array}$ & $\begin{array}{c}\text { Glucose } \\
\text { (pmol per } \\
\text { embryo per 3 h) }\end{array}$ \\
\hline Control & 13 & $0.3 \pm 0.1$ & $46.9 \pm 4.7$ \\
EGF & 18 & $0.3 \pm 0.0$ & $56.0 \pm 4.7$ \\
IGF-1 & 18 & $0.4 \pm 0.0$ & $51.8 \pm 4.7$ \\
EGF + IGF-1 & 14 & $0.3 \pm 0.1$ & $49.8 \pm 4.8$ \\
Serum + hMG & 31 & $0.4 \pm 0.0$ & $61.3 \pm 4.4$ \\
\hline
\end{tabular}

The oocytes were matured for $20 \mathrm{~h}$ in the indicated treatments, fertilized in vitro, and then co-cultured with bovine oviductal epithelial cells until 7 days after insemination. EGF: epidermal growth factor; IGF-I: insulin-like growth factor I; hMG: human menopausal gonadotrophin. Values are means \pm SEM.

effect of treatment on the proportion of cleaved embryos that reached the blastocyst stage by day 7 . The mean number of cells of day 7 blastocysts was significantly greater in the serum + hMG group than in all other treatment groups but there were no differences in glutamine or glucose metabolism among the treatment groups (Table 5).

There was a significant overall effect $(P<0.05)$ of treatment on the proportion of oocytes that developed to the blastocyst stage by day 8 (Table 4 ). This proportion was significantly greater in the EGF + IGF-I group than that in the control group and significantly less than that in the serum +hMG group. There was also a significant overall effect on the proportion of cleaved embryos that developed to the blastocyst stage by day 8: the proportion in the serum + hMG group was significantly greater than that in the control group. There were no differences in the number of cells in the day 8 blastocysts among the treatment groups.

\section{Discussion}

None of the COC in the control group, and all of the COC in the serum $+\mathrm{hMG}$ group underwent cumulus expansion, indicating that expansion does not occur spontaneously under the culture conditions used, but that the COC used were fully able to expand. There was no significant effect of IGF-I alone, while $31.1 \%$ of COC in the EGF group expanded. Moreover, $56.8 \%$ of the COC in the EGF + IGF-I group expanded, suggesting that the effects of the two growth factors are additive. In the mouse, IGF-I similarly had no effect on cumulus expansion while EGF stimulated expansion as did FSH (Downs, 1989). Kobayashi et al. (1994) report that EGF, like LH+FSH, stimulates expansion of $99-100 \%$ of cattle COC, compared with $22.9 \%$ by insulin and $10.2 \%$ of control COC. Lonergan et al. (1996) found that as little as $1 \mathrm{ng}$ EGF $\mathrm{ml}^{-1}$ significantly stimulated cumulus expansion of cattle COC. Lorenzo et al. (1994) also observed that EGF stimulated expansion of cattle COC, but IGF-I had no effect, while there was an additive effect of the two growth factors together.

Glutamine and pyruvate metabolism were significantly greater in oocytes that had been cultured for $20 \mathrm{~h}$ in the presence of serum + hMG than in non-cultured oocytes, and in the control oocytes. Conversely, glucose metabolism was unaffected by time and culture treatment. These results are in close agreement with our previous observations (Rieger and Loskutoff, 1994) and with those of Zuelke and Brackett (1992, 1993).

There were no differences in glutamine or pyruvate metabolism among the EGF, IGF-I and EGF + IGF-I groups. Moreover, neither EGF nor IGF-I alone had any effect on glutamine metabolism compared with the control group. However, EGF + IGF-I significantly stimulated both glutamine and pyruvate metabolism compared with the control group, to values that were not different from that measured in the serum + hMG group. Mean glutamine metabolism was $38 \%$ greater in the EGF + IGF-I group than in the control group, which compares favourably with the observation that mean glutamine metabolism by oocytes cultured with $10 \mu \mathrm{g} \mathrm{LH}$ $\mathrm{ml}^{-1}$ was approximately $26 \%$ greater than by oocytes cultured in medium alone (Zuelke and Brackett, 1993). These observations suggest that EGF and IGF-I together can mimic the stimulatory effects of gonadotrophins on oxidative metabolism in cattle oocytes.

The combined EGF + IGF-I treatment stimulated oocyte maturation over that seen in the control group. This finding suggests that these growth factors are capable of stimulating the maturation of cattle oocytes as well as do gonadotrophins, and is consistent with the reports of Park and Lin (1993), Kobayashi et al. (1994), Lorenzo et al. (1994) and Lonergan et al. (1996). We used exactly the same concentrations of EGF and IGF-I as Lorenzo et al. (1994) and observed treatment means for maturation to metaphase II (MII) that were very similar to their results. Notably, the proportion of MII oocytes in the $\mathrm{EGF}+$ IGF-I group were $8-10 \%$ greater than in the EGF and IGF-I groups in both studies.

In Expt 2 there was no effect of maturation treatment on glucose metabolism of oocytes that had reached metaphase II. Neither was there any significant effect of treatment on glutamine metabolism, although the trend resembled that seen in Expt I; the mean values were greater in the EGF + IGF-I and serum + hMG groups than in the control, EGF and IGF-I groups. Pyruvate metabolism was very similar to that seen in Expt 1 and was significantly greater in the IGF-I, EGF + IGF-I and serum $+\mathrm{hMG}$ groups than in the control group. Most significantly, pyruvate metabolism was greatest in the EGF + IGF-I and serum + hMG groups and they were not different from each other. The results of Expt 2 demonstrate that, in addition to increasing the proportion of oocytes that reach metaphase $\mathrm{Il}$, the combination treatment of EGF + IGF-I also increases the oxidative metabolism of those oocytes that reach this stage.

Gonadotrophins are often used to stimulate the maturation of cattle oocytes in vitro (Crozet, 1991; Brackett and Zuelke, 1993), but at very high concentrations: for example $5 \mu \mathrm{g} \mathrm{LH}$ $\mathrm{ml}^{-1}$ or $500 \mathrm{ng} \mathrm{FSH} \mathrm{ml}^{-1}$ (Kobayashi et al., 1994), $500 \mathrm{ng}$ $\mathrm{LH}$ or FSH ml ${ }^{-1}$ (Harper and Brackett, 1993), $5 \mu \mathrm{g} \mathrm{LH} \mathrm{ml}^{-1}$

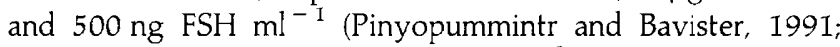
Rosenkrans et al., 1993), $45 \mu \mathrm{g} \mathrm{FSH} \mathrm{ml}{ }^{-1}$ (Barnes et al., 1993). Similarly, Zuelke and Brackett (1993) used $10 \mu \mathrm{g} \mathrm{LH} \mathrm{ml}^{-1}$ to demonstrate its effect on glutamine metabolism in cattle oocytes. However, Dieleman et al. (1983) found mean peak 
concentrations of $7 \mathrm{ng} \mathrm{LH} \mathrm{ml} l^{-1}$ and $1.6 \mathrm{ng} \mathrm{FSH} \mathrm{ml}^{-1}$ in bovine follicular fluid in vivo at $4 \mathrm{~h}$ after the plasma peak of the preovulatory $\mathrm{LH}$ surge. These peak follicular concentrations are 71 and 313 times lower than even the 'low' concentrations used by Harper and Brackett (1993) for the in vitro maturation of cattle oocytes.

In contrast, the stimulation of cumulus expansion, oxidative metabolism and nuclear maturation of cattle oocytes was achieved using concentrations of $50 \mathrm{ng}^{\mathrm{EGF} \mathrm{ml}}{ }^{-1}$ and $100 \mathrm{ng}$ IGF-I $\mathrm{ml}^{-1}$ in the present study and by Lorenzo et al. (1994) and $100 \mathrm{ng} \mathrm{ml}^{-1}$ EGF in the study by Kobayashi et al. (1994). Concentrations of 23-168 ng IGF-I $\mathrm{ml}^{-1}$ have been measured in bovine follicular fluid (Spicer et al., 1988; Spicer et al., 1992; Simpson et al., 1994). We are not aware of any published values for EGF concentrations in bovine follicular fluid, but concentrations of 5-13 $\mathrm{ng} \mathrm{ml}^{-1}$ have been measured in porcine follicular fluid (Hsu et al., 1987).

In Expt 3, EGF alone or in combination with IGF-I significantly stimulated cleavage, consistent with the effects on maturation observed in Expt $I$ and with the observations of Lonergan et al. (1996). However, the cleavage rate was significantly greater in the serum + hMG group than in all other treatment groups, whereas the maturation rate in the serum + hMG group was greater only than the controls in Expt I. Similarly, the proportion of oocytes that reached the blastocyst stage by day 7 was greater in the serum +hMG group than in the control group, and there were more blastocyst cells in the serum + hMG group than in all other maturation treatment groups. The proportion of oocytes and cleaved embryos that reached the blastocyst stage by day 8 was significantly greater in the serum + hMG group than in the control group. Lonergan et al. (1996) observed that development to the blastocyst stage was significantly greater for oocytes matured in the presence of fetal calf serum than for those matured in control medium or in the presence of up to $100 \mathrm{ng} \mathrm{EGF} \mathrm{ml}^{-1}$. These observations suggest that hMG, or some component of fetal calf serum, stimulates or favours cytoplasmic maturation of the oocyte, independent of its effect on nuclear maturation and oxidative metabolism of the oocyte, and cleavage of the early embryo. There were no differences in blastocyst metabolism of glucose or glutamine among the treatment groups, indicating that the maturation treatment had no long term effects on metabolic activity.

In conclusion, a physiological concentration of IGF-I combined with a near-physiological concentration of EGF stimulates cumulus expansion, oxidative metabolism and nuclear maturation of cattle oocytes in vitro. Maturation in the presence of EGF alone, or in combination with IGF-I, significantly increased the cleavage rate compared with the control treatment, but even the combined growth factor treatment was less effective than serum + hMG. Similarly, the number of blastocyst cells at day 7 and the blastocyst rate at day 8 were significantly greater in the serum + hMG group than for all other treatments. Although the experimental design does not permit a direct comparison, it is noteworthy that the effects of the maturation treatments on oocyte pyruvate metabolism generally paralleled their effects on cleavage and subsequent development. Maturation treatment with serum + hMG produced the greatest stimulation of pyruvate metabolism, and the highest rates of nuclear maturation, cleavage and development to the blastocyst stage, and the greatest number of blastocyst cells. The effects of the growth factor treatments on these parameters were intermediate between the control treatment and treatment with serum $+\mathrm{hMG}$. This finding suggests that the stimulation of mitochondrial function favours, or is predictive of, developmental potential. Further investigation is required to determine which component(s) of serum or gonadotrophin treatment is responsible for its effects on cleavage rate and number of blastocyst cells, and the exact relationship between oocyte oxidative metabolism and subsequent development.

The authors thank L. Baraldi Scesi, A. Ponzini, R. Vassena and M. Gironi for their excellent technical assistance, and L. Mauri, T. A. L. Brevini, and E. Manganaro for logistical support. Financial support was provided by Special Project RAIZ (paper no. 165).

\section{References}

Adashi EY (1992) The potential relevance of cytokines to ovarian physiology Journal of Steroid Biochemistry 53 439-444

Barnes F, Endebrock M, Looney C, Powell R, Westhusin M and Bondioli K (1993) Embryo cloning in cattle - the use of in vitro matured oocytes Journal of Reproduction and Fertility $97 \quad 317-320$

Benyosef D, Galiani D, Dekel N and Shalgi R (1992) Rat oocytes induced to mature by epidermal growth factor are successfully fertilized Molecular and Cellular Endocrinology 88 135-141

Brackett BG and Zuelke KA (1993) Analysis of factors involved in the in vitro production of bovine embryos Theriogenology 39 43-64

Crozet N (1991) Manipulation of oocytes and in vitro fertilization Journal of Reproduction and Fertility Supplement 43 235-243

Das K, Stout LE, Hensleigh HC, Tagatz GE, Phipps WR and Leung BS (1991) Direct positive effect of epidermal growth factor on the cytoplasmic maturation of mouse and human oocytes Fertility and Sterility 55 1000-1004

Dieleman SJ, Bevers MM, Poortman J and van Tol HTM (1983) Steroid and pituitary hormone concentrations in the fluid of preovulatory bovine follicles relative to the peak of $\mathrm{LH}$ in the peripheral blood Journal of Reproduction and Fertility $69641-649$

Ding JC and Foxcroft GR (1994) Epidermal growth factor enhances oocyte maturation in pigs Molecular Reproduction and Development 39 30-40

Dorrington JH, Bendell JJ, Chuma A and Lobb DK (1987) Actions of growth factors in the follicle Journal of Steroid Biochemistry 27 405-411

Downs SM (1989) Specificity of epidermal growth factor action on maturation of the murine oocyte and cumulus oophorus in vitro. Biology of Reproduction 41 371-379

Gandolfi F, Pocar P, Luciano AM and Rieger D (1996) The effect of EGF and IGF-I during in-vitro maturation of cattle oocytes on subsequent embryo development and metabolism Theriogenology 45277 (Abstract)

Hammond JM, Mondschein JS, Samaras SE, Smith SA and Hagen DR (1991) The ovarian insulin-like growth factor system Journal of Reproduction and Fertility Supplement 43 199-208

Hammond JM, Samaras SE, Grimes R, Leighton J, Barber J, Canning SF and Guthrie HD (1993) The role of insulin-like growth factors and epidermal growth factor-related peptides in intraovarian regulation in the pig ovary Journal of Reproduction and Fertility Supplement 48 117-125

Harper KM and Brackett BG (1993) Bovine blastocyst development after in vitro maturation in a defined medium with epidermal growth factor and low concentrations of gonadotropins Biology of Reproduction 48 409-416

Hsu CJ. Holmes SD and Hammond JM (1987) Ovarian epidermal growth factor activity: concentrations in porcine follicular fluid during follicular enlargement Biochemical and Biophysical Research Communications 147 242-247

Hyttel P, Xu KP, Smith S and Greve T (1986) Ultrastructure of in-vitro oocyte maturation in cattle Journal of Reproduction and Fertility 78 615-625

Kastrop PMM, Bevers MM, Destree OHJ and Kruip TAM (1991) Protein synthesis and phosphorylation patterns of bovine oocytes maturing in vivo. Molecular Reproduction and Development 29 271-275 
Kobayashi K, Yamashita S and Hoshi H (1994) Influence of epidermal growth factor and transforming growth factor- $\alpha$ on in vitro maturation of cumulus cell-enclosed bovine oocytes in a defined medium Journal of Reproduction and Fertility $100439-446$

Lonergan P, Carolan C, Van Langendonckt A, Donnay I, Khatir H and Mermillod P (1996) Role of epidermal growth factor in bovine oocyte maturation and preimplantation embryo development in vitro. Biology of Reproduction 54 1420-1429

Lorenzo P, Illera MJ, Illera JC and Illera M (1994) Enhancement of cumulus expansion and nuclear maturation during bovine oocyte maturation in vitro by the addition of epidermal growth factor and insulin-like growth factor I journal of Reproduction and Fertility $101697-701$

Mattioli M (1992) Biology of oocyte maturation. In Embryonic Development and Manipulation in Animal Production. Trends in Research and Applications pp 17-28 Eds A Lauria and F Gandolfi. Portland Press, London

Park YS and Lin YC (1993) Effect of epidermal growth factor (EGF) and defined simple media on in vitro bovine oocyte maturation and early embryonic development Theriogenology $39475-484$

Pinyopummintr $\mathrm{T}$ and Bavister BD (1991) In vitro-matured/in vitro-fertilized bovine oocytes can develop into morulae/blastocysts in chemically defined, protein-free culture media Biology of Reproduction $45736-742$

Reed ML, Estrada JL, Illera MJ and Petters RM (1993) Effects of epidermal growth factor, insulin-like growth factor-I, and dialyzed porcine follicular fluid on porcine oocyte maturation in vitro. Journal of Experimental Zoology $26674-78$

Rieger D and Loskutoff NM (1994) Changes in the metabolism of glucose, pyruvate, glutamine and glycine during maturation of cattle oocytes in vitro. Journal of Reproduction and Fertility 100 257-262

Rieger D, Loskutoff NM and Betteridge KJ (1992) Developmentally related changes in the uptake and metabolism of glucose, glutamine and pyruvate by cattle embryos produced in vitro. Reproduction Fertility and Development 4 547-557

Rieger D, Luciano AM, Modina S, Pocar P, Lauria A and Gandolfi F (1995) The effect of EGF and IGF-I on metabolism and nuclear maturation of cattle oocytes Joumal of Reproduction and Fertility Abstract Series 15 Abstract 73

Rosenkrans CF, Zeng GQ, McNamara GT, Schoff PK and First NL (1993) Development of bovine embryos in vitro as affected by energy substrates Biology of Reproduction 49 459-462
Shamsuddin M, Larsson B and Rodriguez-Martinez H (1993) Maturation-related changes in bovine oocytes under different culture conditions Animal Reproduction Science 31 49-60

Simpson RB, Chase CC, Spicer LJ, Vernon RK, Hammond AC and Rae DO (1994) Effect of exogenous insulin on plasma and follicular insulin-like growth factor 1, insulin-like growth factor binding protein activity, follicular oestradiol and progesterone, and follicular growth in superovulated Angus and Brahman cows Journal of Reproduction and Fertility 102 483-492

Sirard MA and Bilodeau S (1990) Effects of granulosa cell co-culture on in vitro meiotic resumption of bovine oocytes Journal of Reproduction and Fertility $\mathbf{8 9}$ 459-465

Spicer LJ, Echternkamp SE, Canning SF and Hammond JM (1988) Relationship between concentrations of insulin-like growth factor- $I$ in follicular fluid and various biochemical markers of differentiation in bovine antral follicles Biology of Reproduction 39 573-580

Spicer LJ, Crow MA, Prendiville DJ, Goulding D and Enright WJ 11992) Systemic but not intraovarian concentrations of insulin-like growth factor-I are affected by short-term fasting Biology of Reproduction 46 920-925

Stern J and Coulam CB (1992) New concepts in ovarian regulation - an immune insight American Journal of Reproductive Immunology 27 136-144

Tsafriri A (1985) The control of meiotic maturation in mammals. In Biology of Fertilization, Vol. 1. Model Systems and Oogenesis pp 221-252 Eds CB Metz and A Monroy. Academic Press Inc., Orlando

Xia P, Tekpetey FR and Armstrong DT (1994) Effect of IGF-I on pig oocyte maturation, fertilization, and early embryonic development in vitro, and on granulosa and cumulus cell biosynthetic activity Molecular Reproduction and Development 38 373-379

Xu KP, Yadav BR, Rorie RW, Plante L, Betteridge KJ and King, WA (1992) Development and viability of bovine embryos derived from oocytes matured and fertilized in vitro and co-cultured with bovine oviducal epithelial cells Journal of Reproduction and Fertility 94 33-43

Zuelke KA and Brackett BG (1992) Effects of luteinizing hormone on glucose metabolism in cumulus-enclosed bovine oocytes matured in vitro. Endocrinology $1312690-2696$

Zuelke KA and Brackett BG (1993) Increased glutamine metabolism in bovine cumulus-cell enclosed and denuded oocytes after in vitro maturation with luteinizing hormone Biology of Reproduction 48 815-820 